\title{
Oxygen isotopic and soluble ionic composition of a shallow firn core, Inilchek glacier, central Tien Shan
}

\author{
Karl J. Kreutz, ${ }^{1}$ Vladimir B. Aizen, ${ }^{2}$ L. DeWayne Gecil, ${ }^{3}$ Cameron P. Wake ${ }^{4}$ \\ ${ }^{1}$ Department of Geological Sciences and Institute for Quaternary and Climate Studies, University of Maine, Orono, Maine 04469-5790, U.S.A. \\ ${ }^{2}$ Donald Bren School of Environmental Science and Management, University of California, Santa Barbara, California 93106-5131, U.S.A. \\ ${ }^{3}$ U. S. Geological Survey, 900 North Skyline Drive, Suite C, Idaho Falls, Idaho 83402, U.S.A. \\ ${ }^{4}$ Climate Change Research Center, Institute for the Study of Earth, Oceans, and Space, University of New Hampshire, Durham, \\ New Hampshire 03824, U.S.A.
}

\begin{abstract}
Oxygen isotopic and soluble ionic measurements made on snow-pit (2 m depth) and firn-core (12.4 $\mathrm{m}$ depth) samples recovered from the accumulation zone $(5100 \mathrm{~m})$ of Inilchek glacier $\left(43^{\circ} \mathrm{N}, 79^{\circ} \mathrm{E}\right)$ provide information on recent (1992-98) climatic and environmental conditions in the central Tien Shan region of central Asia. The combined $14.4 \mathrm{~m}$ snow-pit/firn-core profile lies within the firn zone, and contains only one observed melt feature $\left(10 \mathrm{~m}\right.$ temperature $\left.=-12^{\circ} \mathrm{C}\right)$. Although some post-depositional attenuation of the sub-seasonal $\delta^{18} \mathrm{O}$ record is possible, annual cycles are apparent throughout the isotope profile. We therefore use the preserved $\delta^{18} \mathrm{O}$ record to establish a depth/age scale for the core. Mean $\delta^{18} \mathrm{O}$ values for the entire core and for summer periods are consistent with $\delta^{18} \mathrm{O} / \mathrm{tem}$ perature observations, and suggest the $\delta^{18} \mathrm{O}$ record provides a means to reconstruct past changes in summer surface temperature at the site. Major-ion $\left(\mathrm{Na}^{+}, \mathrm{K}^{+}, \mathrm{Mg}^{2+}, \mathrm{Ca}^{2+}\right.$, $\mathrm{NH}_{4}{ }^{+}, \mathrm{Cl}^{-}, \mathrm{NO}_{3}{ }^{-}, \mathrm{SO}_{4}{ }^{2-}$ ) data from the core demonstrate the dominant influence of dust deposition on the soluble chemistry at the site, and indicate significant interannual variability in atmospheric-dust loading during the 1990s. Anthropogenic impacts on $\mathrm{NH}_{4}^{+}$concentrations are observed at the site, and suggest a summer increase in atmospheric $\mathrm{NH}_{4}{ }^{+}$that may be related to regional agricultural (nitrogen-rich fertilizer use) activities.
\end{abstract}

\section{INTRODUGTION}

The world's polar ice sheets and ice caps are recognized as sensitive archives of ambient atmospheric conditions, and contain a unique record of climatic and environmental change. Snow, firn and ice samples recovered from low-latitude/high-altitude glaciers also have the potential to provide detailed paleo-atmospheric information, as long as such records are collected at sites where post-depositional alteration (e.g. seasonal melting, chemical redistribution) is minimal (Wagenbach, 1989). High-altitude glaciochemical records often have the additional geographic advantages of (1) the ability to record mid-latitude climatic and environmental processes, (2) proximity to long-term meteorological observations, and (3) removal from boundary layer processes, and hence provide sampling of the free troposphere. Widespread glaciation in several central Asian mountain ranges (Himalaya, Karakorum, Pamir and Tien Shan) provides several suitable sites from which ice cores can be recovered and used to investigate critical aspects of the Asian climate system (e.g. Mayewski and others, 1984; Thompson and others, 1995, 1997).

The Tien Shan, along the northern periphery of the Tibetan Plateau (Fig. 1), contain the largest subcontinental glacier system (Pobeda-Khan Tengri massif; 1200 glaciers with a total area of $\sim 4320 \mathrm{~km}^{2}$ ) in the region (Aizen and others, 1997a). Meteorological conditions in the central Tien Shan, responsible for the modern glacier regime, are dominated by the interaction between the Siberian anticyclone

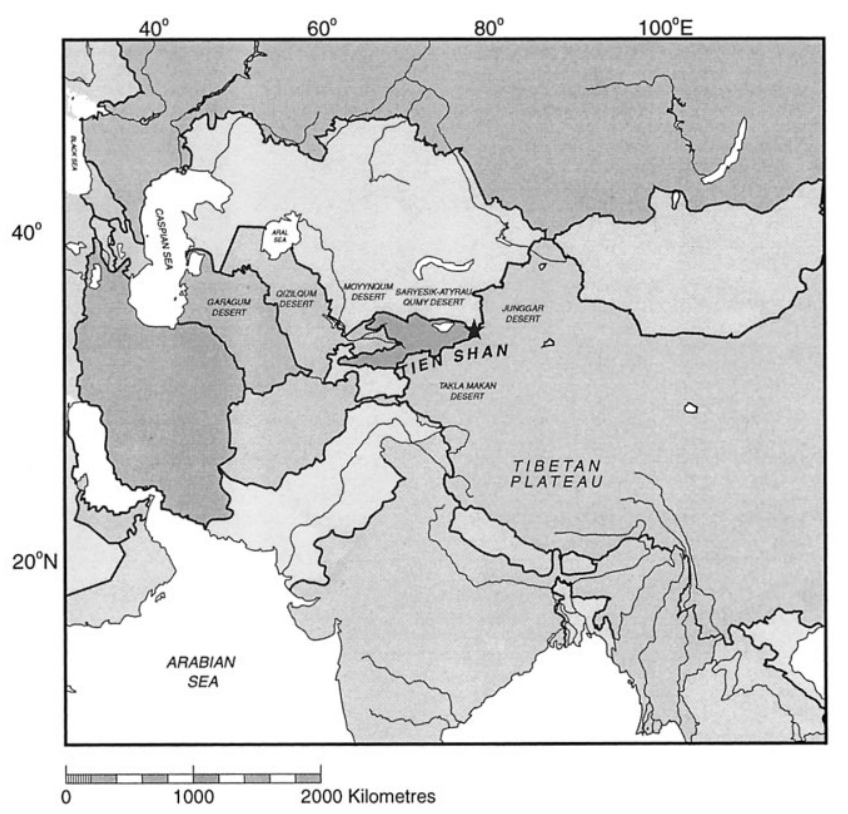

Fig. 1. Regional map of central Asia. The star symbol represents the location of the Inilchek glacier firn-core site.

and western cyclones (Aizen and others, 1996). In summer (June-August), the subtropical and northern jet streams merge and advect moisture to the Tien Shan (Aizen and others, 1993). As a result, the majority of precipitation and hence mass accumulation on glaciers in the Tien Shan occurs during the boreal summer. In addition, the Tien Shan provide a unique setting for studying regional aridity 
and dust transport, as several deserts (Fig. 1) surround the mountain range.

Previous glaciochemical studies in the Tien Shan have demonstrated the strong influence of dust derived from surrounding arid regions (Wake and others, 1992; Williams and others, 1992; Kattelmann and others, 1995). More recently, a simultaneous study of aerosol and snow chemistry in the eastern Tien Shan (Sun and others, 1998) demonstrated good agreement between the chemical composition of the two, and created additional confidence for reconstructing past atmospheric composition based on snow- and ice-core records. In addition, studies of the $\delta^{18} \mathrm{O}$ and $\delta \mathrm{D}$ composition of precipitation in the Tien Shan demonstrate the usefulness of isotope measurements for reconstructing site temperatures and identifying moisture sources (Aizen and others, 1996; Yao and others, 1999). Despite the encouraging results from these studies, and the importance of the central Tien Shan in regional and larger-scale atmospheric and climatic processes, a detailed, multivariate glaciochemical record has not yet been developed from the area.

\section{METHODOLOGY}

To further study glaciochemical characteristics in the region, the relationship between preserved glaciochemistry and climatic processes, and the potential for recovering a longtime-series ice core from the central Tien Shan region, we visited South Inilchek glacier, Kyrgyzstan $\left(42.16^{\circ} \mathrm{N}\right.$, $80.25^{\circ} \mathrm{E}$ ), during July-August 1998 (Fig. 1). Fresh snow samples, snow-pit samples and a shallow firn core were recovered from the accumulation zone at $5100 \mathrm{~m}$ a.s.l. to avoid potential complications from seasonal melting of the snowpack. At the drill site, a $2 \mathrm{~m}$ snow pit was sampled at $5 \mathrm{~cm}$ intervals for chemical measurements by workers wearing non-particulating suits, masks and plastic gloves. Snow samples were placed into pre-cleaned low-density polyethylene (LDPE) containers that had been washed in a sequence of soaking and rinsing with Milli-Q18.2 M $\Omega$ water. Density measurements in the snow pit (using a stainless-steel $100 \mathrm{~cm}^{3}$ box sampler) were made every $3 \mathrm{~cm}$ in a continuous profile. From the bottom of the $2 \mathrm{~m}$ pit, a $12.36 \mathrm{~m}$ firn core $(7.62 \mathrm{~cm}$ diameter) was drilled with a Polar Ice Coring Office (PICO) fiberglass auger $\left(10 \mathrm{~m}\right.$ temperature $\left.=-12^{\circ} \mathrm{C}\right)$. The diameter, length and weight of each core section recovered were measured for density calculation. Snow-pit samples and core sections were packed into insulated shipping containers and transported frozen to the freezers at the University of New Hampshire (UNH).

Core processing at $\mathrm{UNH}$ was done in a dedicated cold room (temperature $<-12^{\circ} \mathrm{C}$ ) using established techniques for ultra-clean sample preparation. Samples for oxygen isotope and major-ion analyses were cut every $7.5 \mathrm{~cm}$. Frozen 18.2 $\mathrm{M} \Omega$ water blanks were sent through the entire system and analyzed often to assure that there was no contamination. Samples were melted immediately prior to ion chromatographic analysis at UNH for water-soluble inorganic ion composition. Anion $\left(\mathrm{Cl}^{-}, \mathrm{NO}_{3}{ }^{-}\right.$and $\left.\mathrm{SO}_{4}{ }^{2-}\right)$ and cation $\left(\mathrm{Na}^{+}\right.$, $\mathrm{Ca}^{2+}, \mathrm{K}^{+}, \mathrm{Mg}^{2+}$ and $\mathrm{NH}_{4}^{+}$) analyses were performed via suppressed ion chromatography (Dionex 4000 series instruments). Cations were analyzed with a CS12 column, $125 \mu \mathrm{L}$ loop and $20 \mathrm{mM}$ methanesulfonic acid (MSA) eluent. Anions were analyzed with an ASll column, $75 \mu \mathrm{L}$ loop, and $6 \mathrm{mM}$ $\mathrm{NaOH}$. Upon melting, an aliquot $(10 \mathrm{~mL})$ of sample was

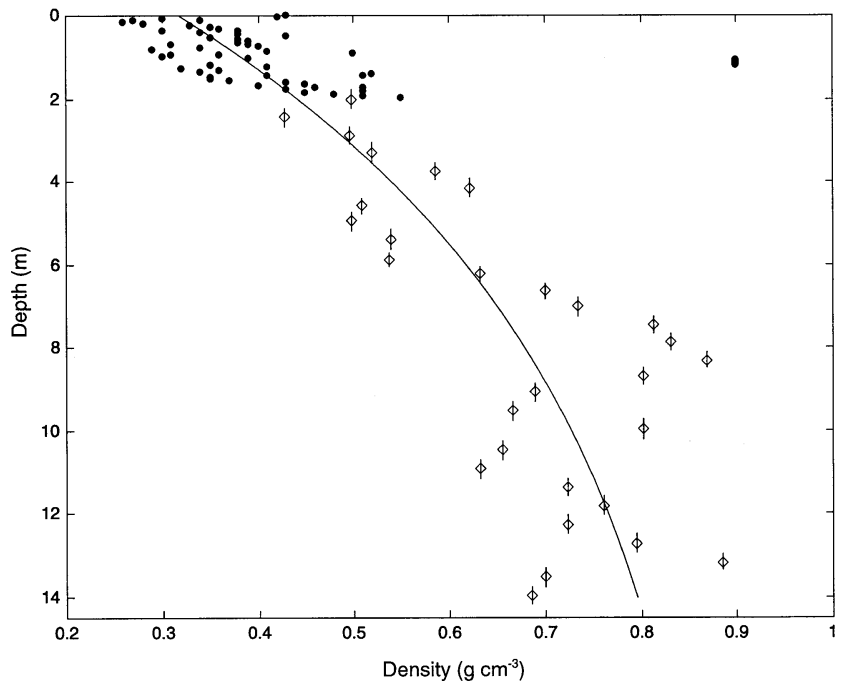

Fig. 2. Density measurements in the upper $14.3 \mathrm{~m}$ of Inilchek glacier. Filled circles represent density measurements made in a $2 \mathrm{~m}$ snow pit; sampling interval is $3 \mathrm{~cm}$. Diamonds represent density measurements made on firn-core sections; sample lengths are represented by vertical bars and range from 34 to $50 \mathrm{~cm}$. The solid line represents the density model described in the text.

removed, refrozen and shipped frozen to the University of Maine for oxygen isotope $\left(\delta^{18} \mathrm{O}\right)$ analysis. A VG-Fisons Sira Series II mass spectrometer fitted with dual inlets, triple collectors and mated to an automated $\mathrm{CO}_{2}$ equilibration device was used for analysis (precision $\pm 0.05 \%$ ). Sample ratios are reported in delta $(\delta)$ notation relative to Vienna standard mean ocean water (V-SMOW) according to the formula (Craig, 1961):

$$
\delta^{18} \mathrm{O}=\left[\left(R_{\text {sample }}-R_{\text {SMOW }}\right) / R_{\text {SMOW }}\right] \times 1000 \% \text { 。 }
$$

Density measurements in the sampled portion of Inilchek glacier are shown in Figure 2. A single ice layer $\left(\rho>0.9 \mathrm{~g} \mathrm{~cm}^{-3}\right)$ was noted at $1.1 \mathrm{~m}$ depth $(0.4 \mathrm{~m}$ w.e. depth) in the snow pit. Below this depth, density values display a characteristic (Paterson, 1981) exponential increase, and do not reach the firn/ice transition at the base of the core. The core is therefore within the firn zone of Inilchek glacier. A density model was fit to the data (Fig. 2):

$$
\rho_{(z)}=\rho_{(\mathrm{i})}-\left[\rho_{(\mathrm{i})}-\rho_{(\mathrm{s})}\right] \exp (-z / 8.5),
$$

where $\rho_{(\mathrm{i})}=0.89 \mathrm{~g} \mathrm{~cm}^{-3}$ (Paterson, 1981), $\rho_{(\mathrm{s})}=0.33 \mathrm{~g} \mathrm{~cm}^{-3}$ (based on the average density of the upper $30 \mathrm{~cm}$ of surface snow) and $z$ is depth. Depth values for isotopic and chemical measurements in the snow pit and firn core were corrected using the above model, and are expressed in terms of waterequivalent depth (WED).

\section{RESULTS AND DISGUSSION}

\subsection{Oxygen isotopes}

To produce a continuous oxygen-isotope $\left(\delta^{18} \mathrm{O}\right)$ record from the glacier surface, data have been combined from the $2 \mathrm{~m}$ snow pit and the $12.36 \mathrm{~m}$ firn core (Fig. 3). Significant variability is apparent in the $\delta^{18} \mathrm{O}$ data with increasing depth, with large-amplitude (range $=29.6 \%$ ) $\delta^{18} \mathrm{O}$ fluctuations present throughout the core. No significant post-depositional effects are apparent in the 1998 firn-core $\delta^{18} \mathrm{O}$ record, as the signal amplitude near the bottom of the core $(6-9 \mathrm{~m}$ WED) is similar to that observed near the surface. Some 


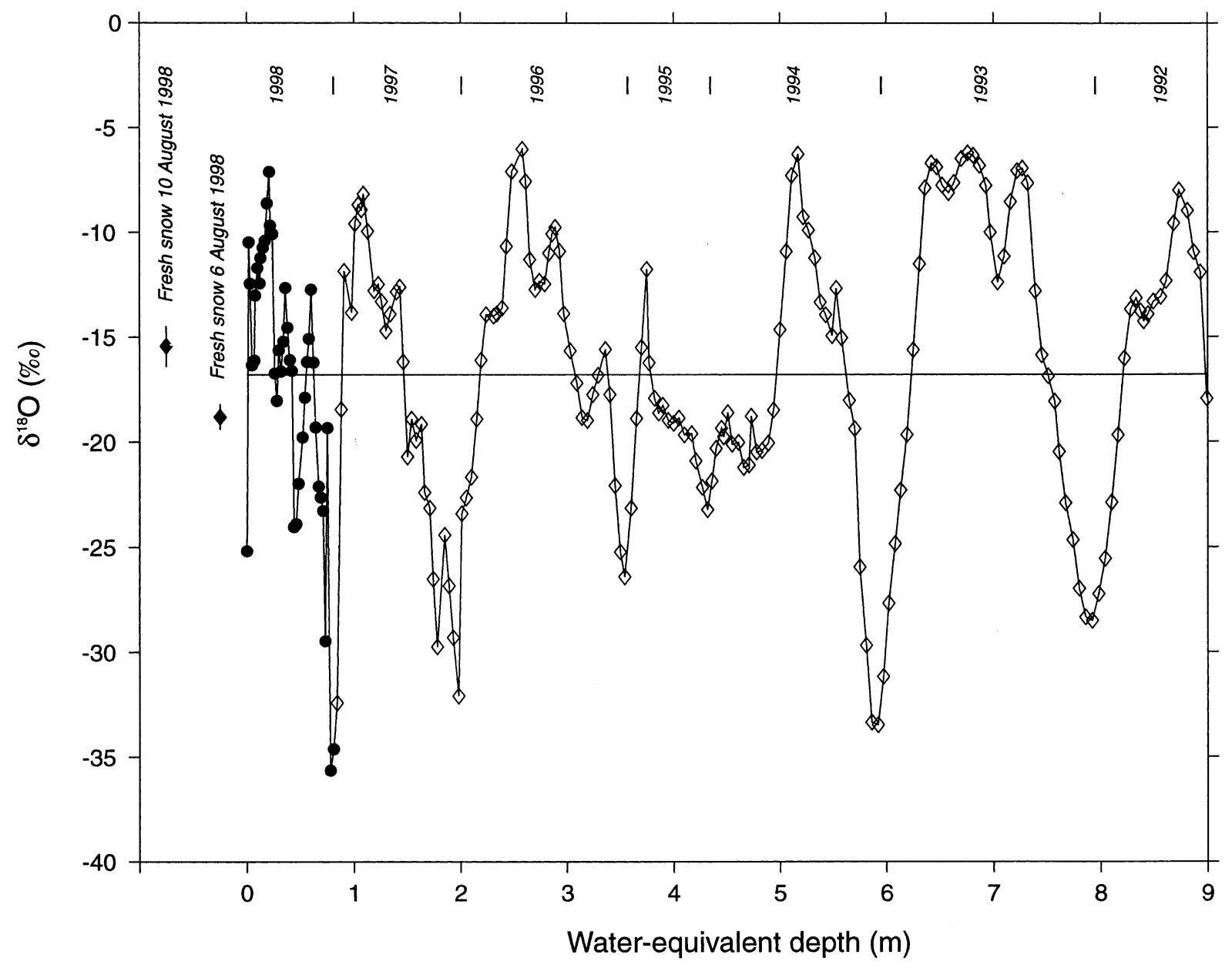

Fig. 3. Oxygen isotopic $\left(\delta^{18} \mathrm{O}\right)$ measurements on the Inilchek glacier firn core. Data from the upper $2 \mathrm{~m}(1 \mathrm{~m}$ w.e.) are from a snow pit sampled at $5 \mathrm{~cm}$ intervals at the drill site; remaining data from the firn core are in $7.5 \mathrm{~cm}$ intervals. Depths in both the snow pit and core have been corrected based on density measurements. Years (1992-97) represent summer intervals, and have been chosen based on $\delta^{18} \mathrm{O}$ maxima and the 1998 sampling period. Fresh-snow data are from two events which occurred during the expedition (error bars represent \pm 1 std dev. of five replicate samples).

attenuation of the sub-seasonal $\delta^{18} \mathrm{O}$ signal, perhaps due to vapor diffusion (Johnsen, 1977), is noted when comparing bottom and top portions of the record. However, part of the discrepancy may be due to different sample intervals in the snow-pit $(5 \mathrm{~cm})$ and firn-core $(7.5 \mathrm{~cm})$ sections of the profile, so the record is too short to adequately assess any diffusion mechanisms. Similar $\delta^{18} \mathrm{O}$ signals have been noted in snow pits from other locations on Inilchek glacier (Aizen and others, 1996), and in a $20 \mathrm{~m}$ core from the Gregoriev ice cap (4660 m a.s.l.), Tien Shan (Thompson and others, 1993; Table 1). We therefore interpret the observed $\delta^{18} \mathrm{O}$ variability as reflecting annual cycles in precipitation $\delta^{18} \mathrm{O}$ at the site (Dansgaard, 1964). Based on this assumption, accumulation years have been defined on the $\delta^{18} \mathrm{O}$ curve (Fig. 3), with $\delta^{18} \mathrm{O}$ maxima corresponding to summer layers. This interpretation $\left(\delta^{18} \mathrm{O}\right.$ maximum during summer) is consistent with observed $\delta^{18} \mathrm{O}$ values in surface snow-pit samples and fresh-snow samples collected during the 1998 field expedi-

Table 1. Summary of oxygen isotope ratios and major-ion concentrations in Tien Shan snow, firn and ice cores

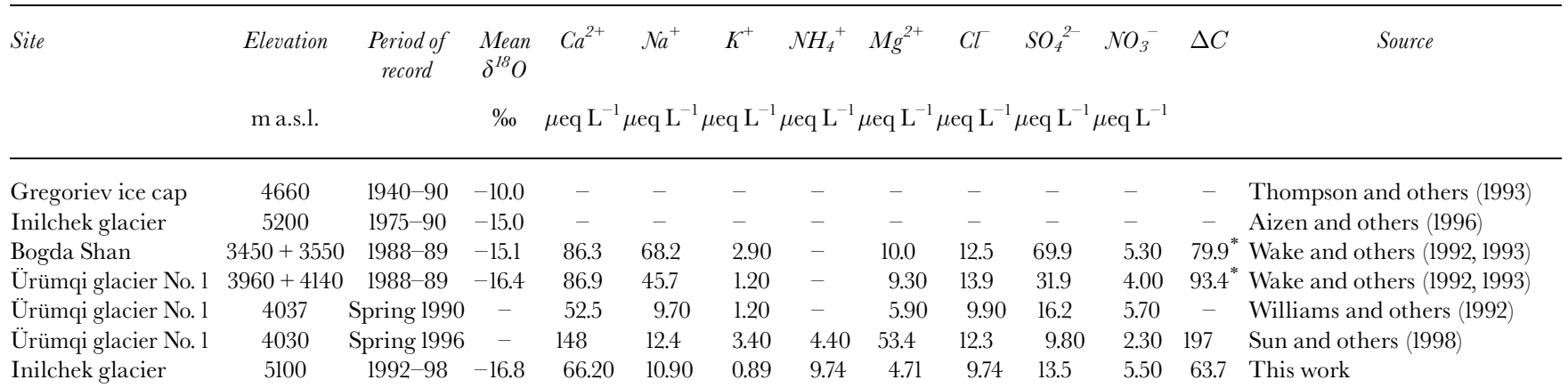

Notes: -, no data available.

$\Delta C=\left(\left[\mathrm{Ca}^{2+}\right]+\left[\mathrm{Na}^{+}\right]+\left[\mathrm{K}^{+}\right]+\left[\mathrm{NH}_{4}{ }^{+}\right]+\left[\mathrm{Mg}^{2+}\right]\right)-\left(\left[\mathrm{Cl}^{-}\right]+\left[\mathrm{SO}_{4}{ }^{2-}\right]+\left[\mathrm{NO}_{3}{ }^{-}\right]\right)$.

${ }^{*} \Delta C$ for 1988-89 Ürümqi glacier No. 1 and Bogda Shan samples does not include $\mathrm{NH}_{4}{ }^{+}$concentrations. 
tion (Fig. 3). Mass-balance (precipitation - (evaporation + sublimation)) estimates indicate a mean accumulation rate of $146 \mathrm{~g} \mathrm{~cm}^{-2} \mathrm{a}^{-1}$ for the period 1993-97 (the snow-pit and firn-core record does not include the full accumulation season for 1992 and 1998, so available data from these years are not included in the mean accumulation estimate). The observed accumulation rate is higher than modeled precipitation estimates $\left(\sim 80 \mathrm{~g} \mathrm{~cm}^{-2} \mathrm{a}^{-1}\right)$ for this altitude in the Inilchek basin (Aizen and others, 1997a), which may be due to basin morphology (i.e. preferential trapping of snow in a sheltered basin; Wake, 1989).

In central Asia, empirical $\delta / T_{\mathrm{s}}$ studies have been performed at several sites using meteorological-station and field temperature data, and the $\delta^{18} \mathrm{O}$ composition of precipitation and preserved snow (Yao and Thompson, 1992; Lin and others, 1995; Yao and others, 1995, 1999; Aizen and others, 1996). Based on these results, several Asian ice-core $\delta^{18} \mathrm{O}$ records have been used to reconstruct past atmospheric temperature changes on $10^{2}-10^{4}$ year time-scales (Thompson and others, 1993, 1995, 1997). Using a limited set of precipitation $\delta^{18} \mathrm{O}$ measurements in the Tien Shan, Aizen and others (1996) concluded that there was likely a single summer moisture source, and derived the following relationship:

$$
\delta^{18} \mathrm{O}(\% \circ)=0.6 T_{\mathrm{s}}-5.6 \text {. }
$$

Because this equation represents the only empirical relationship yet derived from the central Tien Shan, we use it as a basis for interpreting the 1998 Inilchek firn-core $\delta^{18} \mathrm{O}$ record. Using Equation (1), the average yearly $\delta^{18} \mathrm{O}$ maxima $(-7.46 \%)$ and minima $(-29.85 \%)$ present in the Inilchek core record underestimate the mean annual temperature cycle recorded at Tien Shan station $(3614 \mathrm{~m})$. Calculated vs observed temperatures are $-3.1^{\circ}$ and $3.4^{\circ} \mathrm{C}$ for summer (June-August), and $-40.4^{\circ}$ and $-20.2^{\circ} \mathrm{C}$ for winter (December-February), respectively. Given that Tien Shan station lies at a lower altitude, the absolute seasonal temperature cycle at the Inilchek core site is likely colder. Calculated winter values for the Inilchek site, however, appear to be much lower than can be accounted for by standard adiabatic lapse rates. Seasonal differences over the $1500 \mathrm{~m}$ elevation range, including temperature-dependent lapse rates and/or valley effects, may play a role in the winter discrepancy (Grootes and others, 1989). It is therefore likely that the $\delta^{18} \mathrm{O} / T_{\mathrm{S}}$ relationship derived by Aizen and others (1996), based only on coeval summer precipitation sampling and temperature observations, does not correctly approximate $\delta / T_{\mathrm{s}}$ during other seasons. Assuming that $\delta^{18} \mathrm{O}$ maxima mainly represent summer precipitation, and that $\delta^{18} \mathrm{O}$ values during summer are primarily related to $T_{\mathrm{S}}$, there is no apparent trend in summer temperatures at the site during the 1992-98 period. In fact, mean summer $\delta^{18} \mathrm{O}$ values are consistent except for 1995, a year with only onethird the long-term mean precipitation amount at Tien Shan station. Mean summer (June-September) temperatures measured at Tien Shan station (3614 m a.s.l.) also lack any significant trend during 1992-97 (V. Aizen, unpublished data), lending qualitative support to the interpretation of the Inilchek firn-core $\delta^{18} \mathrm{O}$ record.

\subsection{Soluble ions}

Mean ion concentrations in the 1998 Inilchek glacier firn core are given in Table 1. Within the Tien Shan range, snow and firn soluble-ion data are generally in good agreement despite different time periods sampled. To compare the relative contribu-

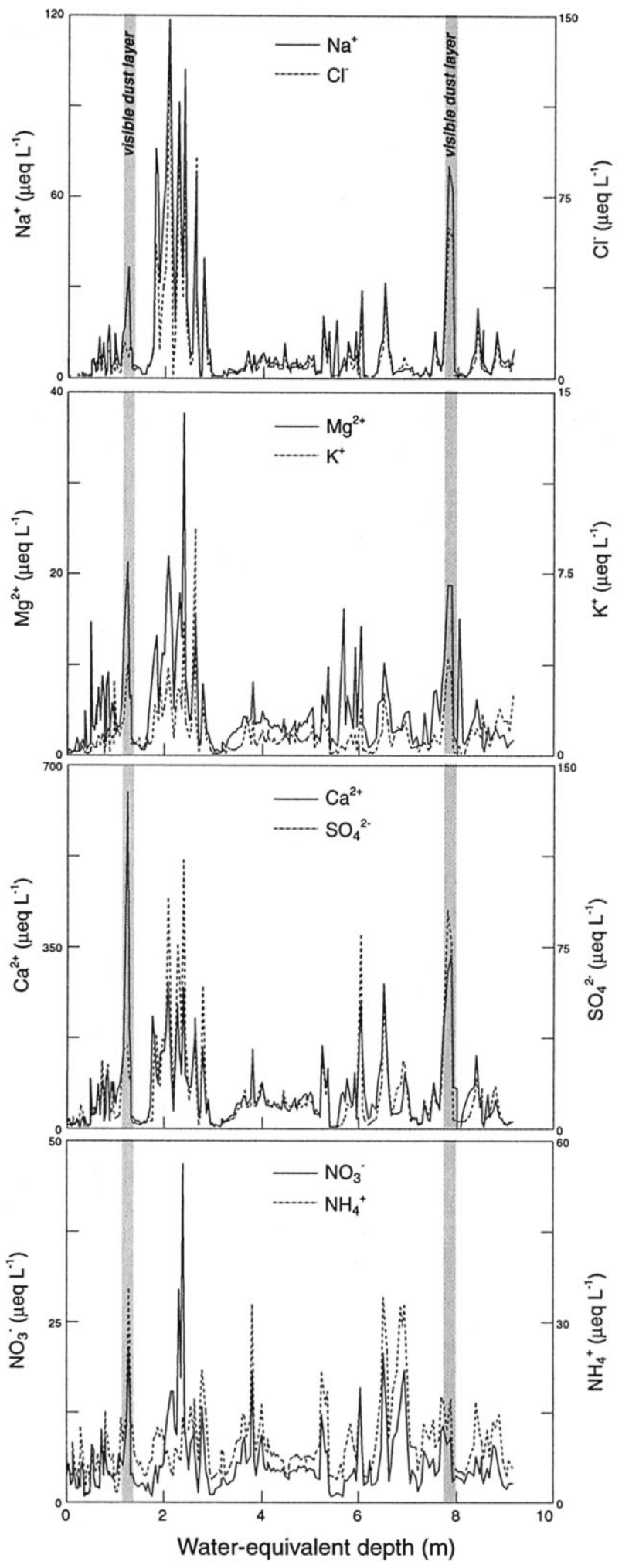

Fig. 4. Soluble-ion measurements made on Inilchek glacier firncore samples. Sampling intervals are the same as those described in Figure 3.

tion of each species to the overall chemical loading, the percentage of total ionic charge was calculated on a sampleby-sample basis and then averaged for the entire core. The cation excess is represented by $\Delta C$, and is calculated by subtracting the anion sum $\left(\Sigma^{-}\right)$from the cation sum $\left(\Sigma^{+}\right)$. The dominant cations are $\mathrm{Ca}^{2+}, \mathrm{NH}_{4}{ }^{+}$and $\mathrm{Na}^{+}$, while $\mathrm{Cl}^{-}$and $\mathrm{SO}_{4}{ }^{2-}$ are the dominant anions. Although not measured, $\mathrm{Ca}^{2+}$ is likely carbonate/bicarbonate, based on estimates of evaporite deposits in the region and glaciochemical measurements made at other Tien Shan sites (Williams and others, 1992). Therefore, 


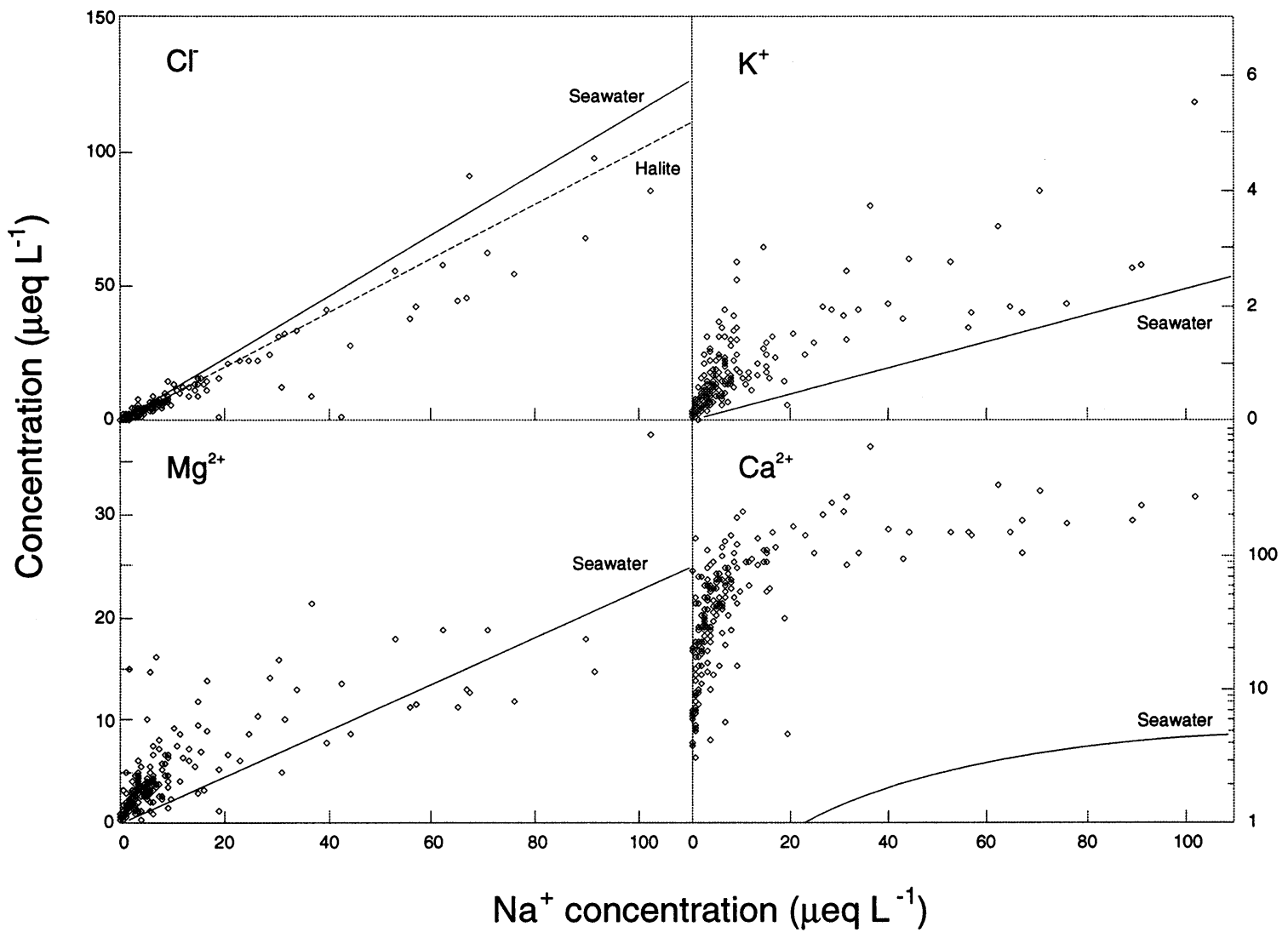

Fig. 5. $\mathrm{Na}^{+}$concentrations in Inilchek glacier firn core us other species $\left(\mathrm{Cl}, \mathrm{Mg}^{2+}, \mathrm{K}^{+}\right.$and $\left.\mathrm{Ca}^{2+}\right)$ with possible marine sources. Conservative sea-water concentration lines are based on data from Drever (1988).

soluble aerosol deposition at the site during the time period covered by this core was dominated by $\mathrm{Ca}^{2+}$ and $\mathrm{HCO}_{3}^{-} /$ $\mathrm{CO}_{3}{ }^{2-}$, suggesting that regional sources of soluble calcite have a strong impact on the precipitation chemistry at this site.

Chemical-species time series from the 1998 Inilchek samples are presented in Figure 4. Episodic dust input is likely the cause of the strong temporal variability in the record, and strong covariance is visually evident in several $\left(\mathrm{Na}^{+}, \mathrm{Cl}^{-}, \mathrm{Mg}^{2+}, \mathrm{K}^{+}, \mathrm{Ca}^{2+}\right.$ and $\left.\mathrm{SO}_{4}{ }^{2-}\right)$ species. Linear regression between water-soluble species indicates a significant (95\% confidence level) correlation between most ions, particularly $\mathrm{Na}^{+}$and $\mathrm{Cl}^{-}$(Table 2 ). These species are generally assumed to have a marine origin, even at some highelevation sites (Shrestha and others, 1997), but scatter-plot estimates reveal a departure from sea-water $\mathrm{Na}^{+} / \mathrm{Cl}^{-}$ratio (0.83; Drever, 1988; Fig. 5). In addition, comparison of $\mathrm{Na}^{+}$ concentrations with other potential marine species (Fig. 5) suggests that sea-water ratios are almost always exceeded,

Table 2. Correlation coefficients between soluble-ion species in the Inilchek firn core

\begin{tabular}{llllllll}
\hline & $\mathrm{Na}^{+}$ & $\mathrm{NH}_{4}^{+}$ & $K^{+}$ & $\mathrm{Mg}^{2+}$ & $\mathrm{Ca}^{2+}$ & $\mathrm{Cl}$ & $\mathrm{NO}_{3}{ }^{-}$ \\
\hline $\mathrm{Na}^{+}$ & & & & & & & \\
$\mathrm{NH}_{4}{ }^{+}$ & 0.18 & & & & & & \\
$\mathrm{~K}^{+}$ & 0.75 & 0.35 & & & & & \\
$\mathrm{Mg}^{2+}$ & 0.81 & 0.26 & 0.69 & & & & \\
$\mathrm{Ca}^{2+}$ & 0.69 & 0.42 & 0.68 & 0.80 & & & \\
$\mathrm{Cl}^{-}$ & 0.95 & 0.20 & 0.77 & 0.76 & 0.64 & & \\
$\mathrm{NO}_{3}{ }^{2-}$ & 0.51 & 0.59 & 0.57 & 0.62 & 0.52 & 0.50 & \\
$\mathrm{SO}_{4}{ }^{2-}$ & 0.86 & 0.43 & 0.72 & 0.83 & 0.76 & 0.85 & 0.73 \\
\hline
\end{tabular}

Note: Sample number is $205 ; r>0.18$ is significant at $p=0.01$. particularly for $\mathrm{Ca}^{2+}$. The regional setting of the site (at least $2400 \mathrm{~km}$ from ocean sources) likely precludes any long-range transport of coarse-mode, primary sea-salt aerosol. Rather, the mean $\mathrm{Na}^{+} / \mathrm{Cl}^{-}$equivalence ratio is 1.24 , suggesting various evaporite (e.g. halite) sources. Terrestrial dusts have also been postulated as the main source of $\mathrm{SO}_{4}{ }^{2-}$ and $\mathrm{NO}_{3}{ }^{-}$in Tien Shan snow (Wake and others, 1990; Williams and others, 1992; Sun and others, 1998). Under alkaline atmospheric conditions, $\mathrm{H}_{2} \mathrm{SO}_{4}$ and $\mathrm{HNO}_{3}$ can be absorbed on the surface of mineral particles and react to form salts (Mamane and Gottlieb, 1992; Mamane and others, 1992). The significant correlation observed between $\mathrm{SO}_{4}{ }^{2-}$ and $\mathrm{NO}_{3}{ }^{-}$(Table 2) suggests that this may be the case in the Inilchek region as well.

Equivalence ratios can provide information for evaluating compounds responsible for soluble-species deposition, so they are useful for estimating chemical sources. For example, $\mathrm{Ca}^{2+}$ may be associated with $\mathrm{SO}_{4}{ }^{2-}$ (gypsum and/or anhydrite) or with $\mathrm{CO}_{3}{ }^{2-}$ (calcite), both originating from evaporite deposits. If gypsum were the primary soluble compound delivering $\mathrm{Ca}^{2+}$ to the site, a mean $\mathrm{Ca}^{2+} / \mathrm{SO}_{4}{ }^{2-}$ equivalence ratio close to 1 would be expected (Fig. 6). This is clearly not the case in the Inilchek glacier core, as the mean $\mathrm{Ca}^{2+} / \mathrm{SO}_{4}{ }^{2-}$ ratio is much higher (6.90), suggesting that $\mathrm{Ca}^{2+}$ is primarily arriving at the site as calcite. There is no apparent seasonal variation in the $\mathrm{Ca}^{2+} / \mathrm{SO}_{4}{ }^{2-}$ ratio. Aizen and others (1997a) noted that synoptic processes favorable for precipitation in the Tien Shan occur from the west, suggesting that aerosol from western Kyrgyzstan, Kazakhstan, Uzbekistan and Turkmenistan may be transported to the site. An intensive aerosol study in Tajikistan during 1989 also noted that meteorological conditions responsible for enhanced atmospheric-dust concentrations involved long-range transport of aerosol from desert regions to the west.

Significant interannual variability in dust deposition to 


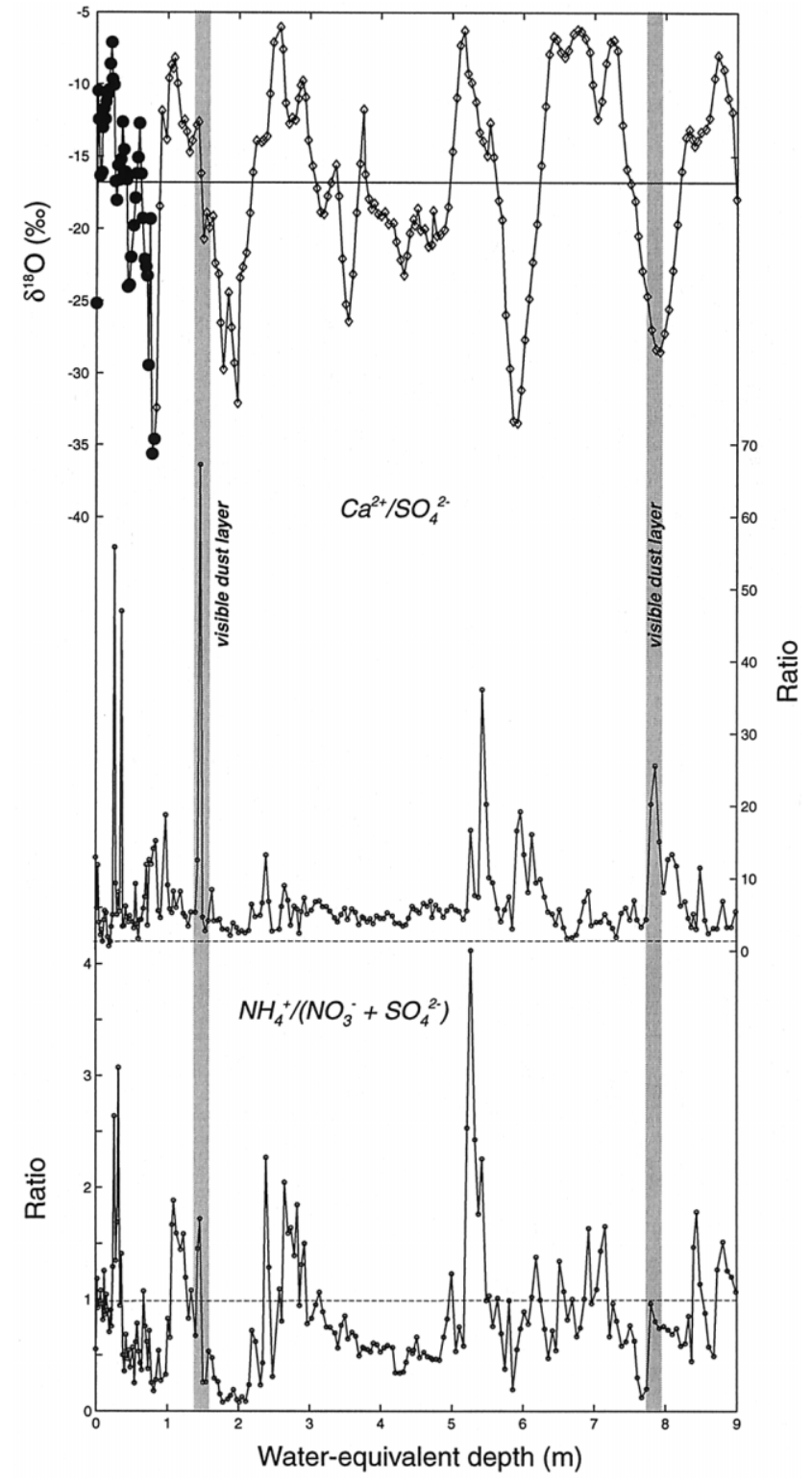

Fig. 6. Equivalence ratios for selected ion species along Inilchek glacier firn core. Also plotted for comparison are the firn-core $\delta^{18} O$ data. The horizontal line on the $\delta^{18} O$ plot represents the mean value, while the horizontal lines on the ratio plots represent an equivalence ratio of 1 .

Inilchek glacier occurred during the period covered by the firn-core record. In particular, the $1996 / 97$ period stands out as having much higher dust input (Fig. 4). Several potential scenarios could be responsible for such an increase in dust flux: (1) increased regional aridity, (2) increased dust-storm frequency and/or transport to the site, or (3) decreased accumulation and enhanced dry deposition. An estimate of accumulation, based on the $\delta^{18} \mathrm{O}$ signal, suggests that this period was not one of significantly reduced accumulation. Therefore, an increase in concentration due only to increased dry deposition is unlikely. We suggest that regional aridity conditions and/or transport efficiency were enhanced and are responsible for the observed increase in dust flux.

Ammonium $\left(\mathrm{NH}_{4}{ }^{+}\right)$has the highest correlation with $\mathrm{SO}_{4}{ }^{2-}$ and $\mathrm{NO}_{3}{ }^{-}$(Table 2), which is consistent with aerosols prevalent in the remote global troposphere (Warneck, 1988). While the mean $\mathrm{NH}_{4}{ }^{+} /\left(\mathrm{NO}_{3}{ }^{-}+\mathrm{SO}_{4}{ }^{2-}\right)$ ratio is below 1 , peaks greater than 1 occur during summer $\left(\delta^{18} \mathrm{O}\right.$ maxima; Fig. 6). Thus, $\mathrm{NH}_{4}{ }^{+}$compounds are minor components in the regional troposphere at times of high dust input, but during summer they are much more significant. Potentially significant local $\mathrm{NH}_{4}{ }^{+}$sources include: (1) biomass burning, (2) livestock, and (3) commercial and natural fertilizers widely used in agricultural activities. Of these sources, $\mathrm{NH}_{4}{ }^{+}$emissions from fertilized soil are estimated to make the dominant contribution to the troposphere (Stedman and Shetter, 1983; Warneck, 1988). Gaseous $\mathrm{NH}_{3}$ released from soils undergoes rapid reaction with strong acids ( $\mathrm{HNO}_{3}$ and $\mathrm{H}_{2} \mathrm{SO}_{4}$ ), so common $\mathrm{NH}_{4}{ }^{+}$-bearing compounds are $\mathrm{NH}_{4} \mathrm{HSO}_{4},\left(\mathrm{NH}_{4}\right)_{2} \mathrm{SO}_{4}$ and $\mathrm{NH}_{4} \mathrm{NO}_{3}$.

Equivalence ratios in the 1998 Inilchek glacier core suggest that these compounds alone cannot explain observed $\mathrm{NH}_{4}{ }^{+}$concentrations. In particular, the $\mathrm{NH}_{4}{ }^{+} /\left(\mathrm{SO}_{4}{ }^{2-}+\right.$ $\mathrm{NO}_{3}{ }^{-}$) ratio exceeds 1 during summer periods (Fig. 6), and during 1994 reaches a value of 4 . The high ratios indicate that there is a vast excess of $\mathrm{NH}_{3}$ emitted to the atmosphere in summer, which reaches the site either in the gas phase or as an $\mathrm{NH}_{4}{ }^{+}$-bearing compound. Previous glaciochemical work has suggested that biomass burning is responsible for the correlation seen between $\mathrm{NH}_{4}{ }^{+}$and organic acids (i.e. formate, $\mathrm{HCOO}^{-}$) in snow- and ice-core records (Legrand and others, 1992; Wake and others, 1992). Because we have not measured organic acids in the Inilchek glacier samples, we cannot rule out biomass-burning products as a source of the excess $\mathrm{NH}_{4}{ }^{+}$. It is not clear, however, that such a biomassburning source would be dominant in summer, as observed in the core record. Rather, we favor a compound that is linked to agricultural activity in the region, and specifically to the use of nitrogen-rich fertilizers that increases in summer. A summer peak in $\mathrm{NH}_{4}{ }^{+}$concentrations has been noted at Colle Gnifetti, Switzerland (4450 ma.s.l.), and was explained by a superposition of atmospheric transport (summer instability and enhanced vertical transport) and European agricultural $\mathrm{NH}_{3}$ emissions (Döscher and others, 1996). We suggest that a similar mechanism is responsible for the observed $\mathrm{NH}_{4}{ }^{+}$concentrations in the Inilchek firn core, related to summer agricultural activity in the region.

\section{GONGLUSIONS}

The isotopic and soluble-ionic records presented here from a shallow firn core indicate that Inilchek glacier provides a sensitive archive of central Asian atmospheric, climatic and environmental conditions. Although a single melt feature was observed in the $14.4 \mathrm{~m}$ profile, it appears possible to reconstruct climate variability without any significant ambiguity introduced by seasonal melting. The preserved annual $\delta^{18} \mathrm{O}$ cycles in the snow and firn sections of the glacier are a means of identifying annual layering, but more accurate depth/age scale construction will require independent verification of $\delta^{18} \mathrm{O}$-based dating (i.e. with radionuclide data). The Inilchek $\delta^{18} \mathrm{O}$ record contains no obvious trend in summer $\delta^{18} \mathrm{O}$ values during the $1992-98$ period, which is consistent with mean summer air temperatures recorded in regional instrumental data. Major-ion data demonstrate the dominance of dust (particularly $\mathrm{CaCO}_{3}$ ) deposition on the water-soluble chemistry of the site, as well as significant interannual variability in dust transport. In addition, given the timing and magnitude of summer $\mathrm{NH}_{4}{ }^{+}$concentrations, we speculate that regional agricultural activity and the use of nitrogen-rich fertilizers have an impact at the Inilchek site. Based on results presented here, a long multivariate icecore record recovered from Inilchek glacier will provide a 
means to investigate climatic and environmental conditions in central Asia and extend reconstructions prior to the instrumental period. Several trends observed in central Asia over the past half-century, namely, increasing temperatures, decreasing precipitation (Aizen and others, 1997b), and aridity (Zhang and Crowley, 1989), can thus be established within a longer climatic context.

\section{AGKNOWLEDGEMENTS}

We thank D. Introne (University of Maine Stable Isotope Laboratory) for oxygen isotope analyses, S. Whitlow (UNH Climate Change Research Center) for major-ion measurements, and the staff and guides of the Tien Shan International Mountaineering Center for assistance in the field. The manuscript was improved by comments from E. Sholkovitz. This work was supported by the U.S. Department of Energy, U.S. Geological Survey, Associated Western Universities, the Postdoctoral Scholar Program at the Woods Hole Oceanographic Institution (funding provided by the Devonshire Foundation) and the U.S. National Science Foundation (ATM-0000560).

\section{REFERENGES}

Aizen, V. B., E. M. Aizen, V. N. Nesterov and D. J. Sexton. 1993. A study of glacial runoff in central Tien Shan during 1989-1990. f. Glaciol. Geocryol., $15(3), 442-459$.

Aizen, V., E. Aizen, J. Melack and T. Martma. 1996. Isotopic measurements of precipitation on central Asia glaciers (southeasternTibetan, northern Himalayas, central Tien Shan). f. Geophys. Res., 101 (D4), 9185-9196.

Aizen, V. B., E. M. Aizen, J. Dozier, J. M. Melack, D. D. Sexton and V. N. Nesterov. 1997a. Glacial regime of the highest Tien Shan mountain, Pobeda-Khan Tengry massif. f. Glaciol., 43(145), 503-512.

Aizen, V. B., E. M. Aizen, J. M. Melack and J. Dozier. 1997b. Climatic and hydrological change in the Tien Shan, central Asia. f. Climate, 10(6), 1393-1404.

Craig, H. 1961. Isotopic variations in meteoric waters. Science, 133(3465), $1702-1703$

Dansgaard, W. 1964. Stable isotopes in precipitation. Tellus, 16(4), 436-468.

Döscher, A., H.W. Gäggeler, U. Schotterer and M. Schwikowski. 1996. A historical record of ammonium concentrations from a glacier in the Alps. Geophys. Res. Lett., 23(20), 2741-2744.

Drever, J. I. 1988. The geochemistry of natural waters. Second edition. Englewood Cliffs, NJ, Prentice-Hall.

Grootes, P. M., M. Stuiver, L. G. Thompson and E. Mosley-Thompson. 1989. Oxygen isotope changes in tropical ice, Quelccaya, Peru. 7. Geophys. Res., 94(D1), 1187-1194.

Johnsen, S. J. 1977. Stable isotope homogenization of polar firn and ice. International Association of Hydrological Sciences Publication 118 (Symposium at Grenoble 1975 - Isotopes and Impurities in Snow and Ice), 210-219.

Kattelmann, R., K. Elder, J. Melack, E. Aizen and V. Aizen. 1995. Some surveys of snow chemistry in the Tien Shan of Kirghizstan and Kazakhstan. International Association of Hydrological Sciences Publication 228 (Symposium at Boulder 1995 - Biogeochemistry of Seasonally Snow-Covered Catchments), 185-190.

Legrand, M., M. de Angelis, T. Staffelbach, A. Neftel and B. Stauffer. 1992.
Large perturbations of ammonium and organic acids content in the Summit-Greenland ice core: fingerprint from forest fires? Geophys. Res. Lett., 19(5), 473-475.

Lin, P. N., L. G. Thompson, M. E. Davis and E. Mosley-Thompson. 1995. 1000 years of climatic change in China: ice-core $\delta^{18} \mathrm{O}$ evidence. Ann. Glaciol., 21, 189-195.

Mamane, Y. and J. Gottlieb. 1992. Nitrate formation on sea-salt and mineral particles - a single particle approach. Atmos. Environ., Ser. A, 26(9), 1763-1769.

Mamane, Y., T. G. Dzubay and R. Ward. 1992. Sulfur enrichment of atmospheric minerals and spores. Atmos. Environ., 26(6), 1113-1120.

Mayewski, P. A., W. B. Lyons, N. Ahmad, G. Smith and M. Pourchet. 1984. Interpretation of the chemical and physical time-series retrieved from Sentik Glacier, Ladakh Himalaya, India. 7. Glaciol., 30(104), 66-76.

Paterson, W. S. B. 1981. The physics of glaciers. Second edition. Oxford, etc., Pergamon Press.

Shrestha, A. B., C. Wake and J. Dibb. 1997. Chemical composition of aerosol and snow in the high Himalaya during the summer monsoon season. Atmos. Environ., 31(17), 2815-2826.

Stedman, D. H. and R. E. Shetter. 1983. The global budget of atmospheric nitrogen species. Adv. Environ. Sci. Technol., 12, 411-454.

Sun Junying and 6 others. 1998. Soluble species in aerosol and snow and their relationship at Glacier 1, Tien Shan, China. 7. Geophys. Res., 103(D21), 28,021-28,028.

Thompson, L. G. and 6 others. 1993. "Recent warming": ice core evidence from tropical ice cores with emphasis on central Asia. Global Planet. Change, 7(1-3), 145-156.

Thompson, L. G. and6 others. 1995. A 1000 year climatic ice-core record from the Guliya ice cap, China: its relationship to global climate variability. Ann. Glaciol., 21, 175-181.

Thompson, L. G. and 9 others. 1997. Tropical climate instability: the last glacial cycle from a Qinghai-Tibetan ice core. Science, 276(5320), 1821-1825.

Wagenbach, D. 1989. Environmental records in alpine glaciers. In Oeschger, H. and C. C. Langway, Jr, eds. The environmental record in glaciers and ice sheets. Chichester, etc., John Wiley and Sons, 69-83.

Wake, C. P. 1989. Glaciochemical investigations as a tool for determining the spatial and seasonal variation of snow accumulation in the central Karakorum, northern Pakistan. Ann. Glaciol., 13, 279-284.

Wake, C. P., P. A. Mayewski and M. J. Spencer. 1990. A review of central Asian glaciochemical data. Ann. Glaciol., 14, 301-306.

Wake, C. P., P. A. Mayewski, Wang Ping, Yang Qinzhao, Han Jiankang and Xie Zichu. 1992. Anthropogenic sulfate and Asian dust signals in snow from Tien Shan, northwest China. Ann. Glaciol., 16, 45-52.

Wake, C. P., P. A. Mayewski, Xie Zichu, Wang Ping and Li Zhongqin. 1993. Regional distribution of monsoon and desert dust signals record in Asian glaciers. Geophys. Res. Lett., 20(14), 1411-1414.

Warneck, P. 1988. Chemistry of the natural atmosphere. San Diego, CA, Academic Press.

Williams, M.W., K. A. Tonnessen, J. M. Melack and Yang Daqing. 1992. Sources and spatial variation of the chemical composition of snow in the Tien Shan, China. Ann. Glaciol., 16, 25-32.

Yao Tandong and L. G. Thompson. 1992. Trends and features of climatic changes in the past 5000 years recorded by the Dunde ice core. Ann. Glaciol., 16, 21-24.

Yao Tandong, L. G. Thompson, Jiao Keqin, E. Mosley-Thompson and Yang Zhihong. 1995. Recent warming as recorded in the Qinghai-Tibetan cryosphere. Ann. Glaciol., 21, 196-200.

Yao Tandong, V. Masson, J. Jouzel, M. Stiévenard, W. Sun and K. Jiao. 1999. Relationship between $\delta^{18} \mathrm{O}$ in precipitation and surface air temperature in the Ürümqi river basin, east Tianshan mountains, China. Geophys. Res. Lett., 26(23), 3473-3476.

Zhang, J. and T. J. Crowley. 1989. Historical climate records in China and reconstruction of past climates. 7. Climate, 2(8), 833-849. 